\title{
The perspective of caregivers of people with Parkinson's: an integrative review
}

Dharah Puck Cordeiro Ferreira' Maria das Graças Wanderley de Sales Coriolano² Carla Cabral dos Santos Accioly Lins'

\section{Abstract}

Objective: to analyze scientific production regarding the process of caring for persons with Parkinson's Disease (PD) from the perspective of the caregiver. Method: a descriptive integrative review type study was performed, guided by the question: How does the caregiver perceive the process of caring for a person with Parkinson's? A search was performed of the Latin American and Caribbean Health Sciences, Nursing Database and Online Search System and Medical Literature Analysis databases, applying the cut-off points 2005 and 2015. Result: following Content Analysis three categories emerged: a) the process of caring for a person with PD; b) the positive and negative aspects associated with the process of caring for a person with PD; c) support for caregivers of people with PD: what can be done for them? Conclusion: The challenge of caring for a person with PD needs to be recognized by caregivers, professionals and health managers as a tool for the (re) construction of care.

\footnotetext{
Universidade Federal de Pernambuco, Programa de pós-graduação em Neuropsiquiatria e Ciências do Comportamento. Recife, PE, Brasil.

2 Universidade Federal de Pernambuco, Departamento de Anatomia Humana. Programa de Pós-Graduação em Gerontologia. Recife, PE, Brasil.
}

Keywords: Caregivers. Parkinson Disease. Elderly. Quality of life. 


\section{INTRODUCTION}

Parkinson's disease (PD) is a complex neurological condition arising from the degeneration of the dopaminergic neurons of the substantia nigra, and most severely affects the ventrolateral layer ${ }^{1,2}$. Motor disorders such as bradykinesia, tremors and stiffness are frequently observed ${ }^{1}$. This results in not only physical but also psychological impairment, through the presence of non-motor symptoms, such as cognitive dysfunction and mood disorders, which can result in disability, social isolation and reduced quality of life $\mathrm{l}^{2,3}$.

Therefore, non-motor symptoms generally prevail at the onset of the pathological process of $\mathrm{PD}$, beginning in the non-dopaminergic structures of the brain or the peripheral nervous system ${ }^{1}$.

Day-to-day living with PD is usually a challenge, as postural instability, movement difficulties, and other signs and symptoms can compromise the functional capacity, independence and autonomy of sufferers, necessitating assistance in the performance of daily activities, such as dressing and feeding oneself, as well as in the instrumental activities of daily living, which are related to the administration of the environment $t^{4}$.

The need therefore arises for a caregiver to be present to assist in the carrying out of such activities, to preserve biopsychosocial well-being and consequently quality of life. In addition, the caregiver is responsible for encouraging self-care, which is performed by a third party only when the PD patient is truly incapable of carrying out such activities ${ }^{4}$.

It is worth noting that the construction of the care process extends throughout the life experience of the family caregiver and is guided by the reality of the family, as well as by the guidance provided by multi-professional medical team, support groups and associations ${ }^{5}$.

Therefore, the care provided guides relationships of care through interaction and transformation, resulting in relations of accountability and affective involvement with another individual ${ }^{6}$, in addition to being more effective when performed with a positive attitude ${ }^{7}$.
Sometimes, however, caring is marked by impersonality and distance, making it increasingly necessary to implement an expanded conception of healthcare for the elderly, whether through interdisciplinary care or in a family environment ${ }^{8}$.

Although studies with a quantitative approach contribute to the development of the theoretical and technical basis of care, the caregiver should be involved in such a research to a greater degree.

Therefore, the development of new research and techniques is fundamental, since publications on the subject have resulted in a number of gaps in knowledge due to the scarcity of productions related to the perception of this process through studies with a qualitative approach. Given this context, the objective of the present study was to analyze the scientific production regarding the process of caring for an individual with Parkinson's disease.

\section{METHOD}

A descriptive integrative review type study was performed, allowing completed studies to be analyzed and conclusions to be reached on the topic of interest by analyzing significant studies for Evidence-Based Practice, collaborating to deepen knowledge and applicability'.

In order to apply methodological rigor, six stages were adopted in the preparation process ${ }^{10}$.

$1^{\text {st }}$ Stage: Establishing of hypothesis or research question - considering the purpose of the study, the integrative review began with the choice and definition of the theme, which was the process of caring for a person with $\mathrm{PD}$, a question which has relevance to clinical practice and the scientific area.

The keywords in the present study, "Parkinson's Disease", "Caregivers" and "Elderly", were used to survey the articles, and were cross-checked with the use of Boolean AND. All are included in the Health Sciences Descriptors (DeCS).

To guide the theme proposed in the article, the following question was elaborated: How does the caregiver perceive the process of caring for a person with Parkinson's? 
$2^{\text {nd }}$ Stage: literature search - a bibliographic survey of the period between May and July 2015 was carried out, with the following inclusion criteria for the search and selection applied: a) articles dealing with the proposed theme; b) articles published between 2005-2015; c) articles in English and/or Spanish and/or Portuguese; d) articles classified as evidence level 5; e) articles that fulfilled the criteria proposed by the Critical Appraisal Skills Program (CASP) Checklist for Qualitative Research. Criteria d) and e) will be explored later in the present study. Articles repeated among the databases were excluded.

Through free electronic access provided by the Biblioteca Virtual de Saúde (the Virtual Health Library) (BVS), the following databases were surveyed: Literatura Latino-Americana e do Caribe em Ciências de Saúde (Latin American and Caribbean Health Sciences Literature) (LILACS), Base de Dados em Enfermagem (the Nursing Database) (BDENF) and the Medical Literature Analysis and Retrieval System Online (MEDLINE).

The articles were independently selected by three reviewers, in order to guarantee the reliability and validity of the study in question.

$3^{\text {rd }}$ Stage: Categorization of studies - the instrument chosen to gather, organize and synthesize information was a validated form, which allows the acquisition of data relating to the identification of the original article and authors, the methodological characteristics, the level of evidence, the interventions measured and the results obtained ${ }^{11}$.

However, this instrument was adapted to the reality of the study by including the following topics: periodical, year of publication, database and CASP classification, which were systematized and resulted in the elaboration of a database completed after data collection (Figure 4).

$4^{\text {th }}$ Stage: evaluation of the studies included in the integrative review - the critical analysis of the data was performed after the numerical organization of the articles surveyed based on the order in which they were found. Based on the objective of the study, we chose to use articles with a qualitative approach, so all were classified as having a level of evidence of five (100\%), according to the selection criteria proposed in the study ${ }^{12}$. A standardized evaluation tool, entitled CASP For Qualitative Research, was also applied, with the objective of critically analyzing the methodology of the studies, to guarantee the methodological rigor, relevance and credibility required for an integrative review of studies with a qualitative approach ${ }^{13}$. According to Volkmer et al. ${ }^{14}$ this contains the following ten systematic items:

1) a clear and justified aim. 2) a methodological design appropriate for the aim. 3) methodological procedures presented and discussed. 4) intentional sample selection. 5) data collection described, instruments and saturation process explained. 6) relationship between researcher and researcher. 7) ethical care. 8) dense and substantiated analysis. 9) results presented and discussed, pointing out the aspect of credibility and the use of triangulation. 10) description of the contributions and implications of the knowledge generated by the research, as well as its limitations.

Following this analysis, the articles were classified as either A, for studies which had a small risk of bias and fulfilled at least nine of the ten items, or B, for studies which had a moderate risk of bias and fulfilled five to ten items ${ }^{13}$. Based on the critical analysis of each selected study, all those in the sample were classified as A, which guarantees the methodological rigor of the study in question.

$5^{\text {th }}$ Stage: interpretation of results - in this stage the discussion of the main results found in literature relating to the process of caring for a person with PD was carried out, allowing existing gaps to be identified, as well as factors that affect the care of the PD sufferer and, as such, interfere with the caregiver's own life.

$6^{\text {th }}$ Stage: presentation of integrative review - the results and discussion were presented in a descriptive manner, through the use of the main table referred to above, which contained information referring to the sample of articles, and schematic drawings that represented subjects pertinent to the process of caring for a person with PD. 


\section{RESULTS}

A total of 198 articles were identified, which were submitted to the following predetermined inclusion and exclusion criteria (Figure 1).

The final sample resulted in four articles published in the period between 2008 and 2012, which were presented through a systematized synthesis (Figure 2) and submitted to full analysis.
In addition, all the research designs of the studies in the sample adopted the qualitative approach, which was one of the inclusion criteria, based on the perception of people who experienced a certain phenomenon, and using techniques to describe, explore and interpret this studied phenomenon ${ }^{15}$.

In terms of the identification of the sources, the articles were localized through MEDLINE. It should be noted that this evidence was not defined as an inclusion criterion, but as a random finding.

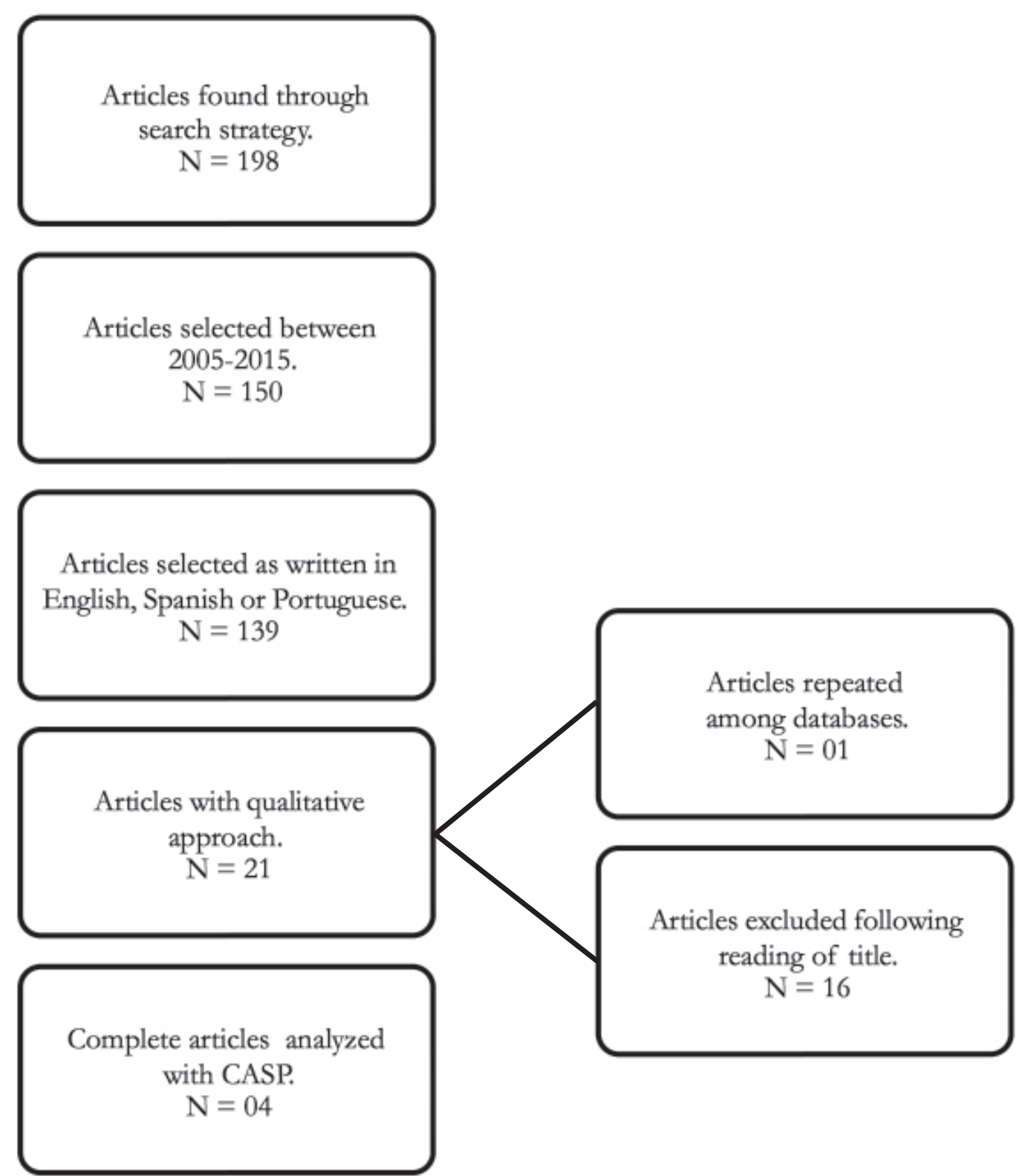

Figure 1. Schematic drawing of obstacles arising from the process of caring for persons affected by Parkinson's Disease. Recife, Pernambuco, 2015. 
Figure 2. Synthesis of articles inserted in the integrative review according to year, periodical, title, authors, approach, level of evidence, type of analysis, database and results. Recife, Pernambuco, 2015.

\begin{tabular}{|c|c|c|c|c|}
\hline Periodical & Title & $\begin{array}{c}\text { Authors/ } \\
\text { Year }\end{array}$ & $\begin{array}{c}\text { Approach/ } \\
\text { Level of evidence/ } \\
\text { Type of analysis/ } \\
\text { Database/ } \\
\text { CASP Classification }\end{array}$ & Results* \\
\hline $\begin{array}{c}\text { Journal of } \\
\text { Clinical } \\
\text { Nursing }\end{array}$ & $\begin{array}{c}\text { Experiences of } \\
\text { caregivers of people } \\
\text { with Parkinson's } \\
\text { disease in Singapore: } \\
\text { a qualitative analysis. }\end{array}$ & $\begin{array}{l}\text { Tan SB, } \\
\text { Williams AF, } \\
\text { Morris ME. } \\
2012^{17}\end{array}$ & $\begin{array}{l}\text { Qualitative } \\
5 \\
\text { MEDLINE } \\
\text { Structural analysis } \\
\text { of NVIVO } 8 \\
\text { A }\end{array}$ & $\begin{array}{l}\text { Following analysis of the discourse } \\
\text { of } 21 \text { caregivers in Singapore, four } \\
\text { themes emerged: a) Confrontation } \\
\text { and adaptation; b) Challenges of } \\
\text { caregivers; c) Effects of care on } \\
\text { caregivers; d) The need for better } \\
\text { support for caregivers. }\end{array}$ \\
\hline $\begin{array}{l}\text { Palliative } \\
\text { Medicine }\end{array}$ & $\begin{array}{l}\text { Living and coping } \\
\text { with Parkinson's } \\
\text { disease: perceptions } \\
\text { of informal carers. }\end{array}$ & $\begin{array}{l}\text { McLaughlin D, } \\
\text { Hasson F, } \\
\text { Kernohan WG, } \\
\text { Waldron M, } \\
\text { Mclaughlin M, } \\
\text { Cochrane B et al. } \\
2011^{18}\end{array}$ & $\begin{array}{c}\text { Qualitative } \\
5 \\
\text { MEDLINE } \\
\text { Analysis of content } \\
\text { A }\end{array}$ & $\begin{array}{l}\text { Following analysis of the discourse } \\
\text { of } 26 \text { caregivers in Northern Ireland, } \\
\text { four themes emerged: a) Medical } \\
\text { support for people with Parkinson's } \\
\text { Disease; b) Overload related to the } \\
\text { care provided; c) Information needs; } \\
\text { d) Economic implications of caring. }\end{array}$ \\
\hline $\begin{array}{l}\text { Movement } \\
\text { Disorders }\end{array}$ & $\begin{array}{l}\text { An exploration of the } \\
\text { burden experienced } \\
\text { by spousal caregivers } \\
\text { of individuals with } \\
\text { Parkinson's disease. }\end{array}$ & $\begin{array}{c}\text { Roland KP, } \\
\text { Jenkins ME, } \\
\text { Johnson AM. } \\
2010^{19}\end{array}$ & $\begin{array}{l}\text { Qualitative } \\
5 \\
\text { MEDLINE } \\
\text { Personal construct } \\
\text { technique and } \\
\text { analysis of main } \\
\text { components } \\
\text { A } \\
\end{array}$ & $\begin{array}{l}\text { After analyzing the discourse of } \\
\text { five caregivers in Canada, three } \\
\text { themes emerged: a) the burden of } \\
\text { social isolation; (b) the burden of } \\
\text { safety concerns; d) the importance of } \\
\text { adequate education and support. }\end{array}$ \\
\hline $\begin{array}{c}\text { Social } \\
\text { Science \& } \\
\text { Medicine }\end{array}$ & $\begin{array}{l}\text { Caregivers' } \\
\text { experiences of caring } \\
\text { for a husband with } \\
\text { Parkinson's disease } \\
\text { and psychotic } \\
\text { symptoms. }\end{array}$ & $\begin{array}{l}\text { Williamson C, } \\
\text { Simpson J, } \\
\text { Murray CD. } \\
2008^{20}\end{array}$ & $\begin{array}{c}\text { Qualitative } \\
5 \\
\text { MEDLINE } \\
\text { Phenomenological } \\
\text { analysis } \\
\text { A }\end{array}$ & $\begin{array}{l}\text { After analyzing the discourse of ten } \\
\text { caregivers in England, four themes } \\
\text { emerged: a) "Trying to find out for } \\
\text { myself": uncertainty and the search } \\
\text { for understanding; b) "Learning to } \\
\text { live with it": adapting responses to } \\
\text { symptoms over time; d) "He's not } \\
\text { usually like this": the contribution of } \\
\text { psychosis to the change of identity; } \\
\text { D) "We aren't so bad, compared to } \\
\text { them": the use of social comparison } \\
\text { as a coping strategy }\end{array}$ \\
\hline
\end{tabular}

* Free translation

While the descriptor "elderly" was used during data collection, the age of the PD sufferers who received care was not defined in the studies. However, the age of the caregivers ranged from 31 to 79 years of age, with a prevalence of elderly persons. However, when the sample was analyzed, it was found that the most commonly used descriptors were "Parkinson's disease", which was present in four studies, followed by "quality of life" in two studies, while the other descriptors, such as "caregivers" and "qualitative research" appeared in only one study.

The profile of the caregivers in the articles selected for this integrative review is summarized in Figure 3, and describes sample size, gender, age and the relationship between the caregiver and the individual with Parkinson's disease. Therefore, the fact that the caregivers of this study were classified as informal was a random finding. 
The articles on the perceptions of the family caregivers about PD were from different journals: the Journal of Clinical Nursing, Palliative Medicine, Movement Disorders and Social Science \& Medicine.

As for the country of origin of the articles, each came from a different location, two from from North America (Canada) and one from Asia (Singapore). All the articles were published in the English language.

With regard to the objectives of each study, all the articles adequately met the requirements of this study and were presented clearly, in a way that facilitated the understanding of the reader. The description of the problems to be investigated was also noted, and there were no discrepancies between the type of objective and the method selected. The final considerations or conclusion were presented at the end, while one study presented a topic on relevance to clinical practice following the conclusion.

Figure 3. Synthesis of the sample data of articles inserted in the integrative review. Recife, Pernambuco, 2015.

\begin{tabular}{|c|c|c|c|c|}
\hline Title of article & Sample & Gender & Age (years) & Relationship \\
\hline $\begin{array}{l}\text { Experiences of caregivers of people } \\
\text { with Parkinson's disease in Singapore: } \\
\text { a qualitative analysis }{ }^{17}\end{array}$ & 21 & $\begin{array}{c}\text { Female: } 17 \\
\text { Male: } 04\end{array}$ & $\begin{array}{c}\text { 31-40: } 03 \\
\text { 41-50: } 02 \\
\text { 51-60: } 08 \\
\text { 61-70: } 07 \\
\text { >71: } 01\end{array}$ & $\begin{array}{l}\text { Husband/wife: } 14 \\
\text { Son/daughter: } 05 \\
\text { Friend: } 02\end{array}$ \\
\hline $\begin{array}{c}\text { Living and coping with Parkinson's } \\
\text { disease: perceptions of informal } \\
\operatorname{carers}^{18} \text {. }\end{array}$ & 26 & $\begin{array}{c}\text { Female: } 17 \\
\text { Male: } 09\end{array}$ & $\begin{array}{l}<55: 05 \\
>55: 21\end{array}$ & Husband/wife: 26 \\
\hline $\begin{array}{l}\text { An exploration of the burden } \\
\text { experienced by spousal caregivers of } \\
\text { individuals with Parkinson's disease }{ }^{19} \text {. }\end{array}$ & 05 & Female: 05 & 49-71: 05 & Wife: 05 \\
\hline $\begin{array}{l}\text { Caregivers' experiences of caring for a } \\
\text { husband with Parkinson's disease and } \\
\text { psychotic symptoms }{ }^{20} \text {. }\end{array}$ & 10 & Female: 10 & 63-79: 10 & Wife: 05 \\
\hline
\end{tabular}

Source: Authors' own work.

\section{DISCUSSION}

The process of care and the caregiver of an individual with PD are fundamental discussion points for global public health, considering that there has been a significant change in the epidemiological profile of the population, in which there is currently a prevalence of chronic non-communicable diseases, making the presence of caregivers increasingly evident and active in society ${ }^{16}$.

Following content analysis, three thematic categories emerged: a) the process of caring for a person with Parkinson's Disease; b) the positive and negative aspects associated with the process of caring for a person with Parkinson's Disease; c) support for caregivers of people with Parkinson's Disease: what can be done for them?

\section{The process of caring for a person with Parkinson's Disease}

According to the reports of the caregivers, the process of caring for an individual with PD can imply careful observation of aspects such as the impairment of body balance and a consequent increase in falls, which cause anxiety, worry and fear. From this perspective, one of the ways of dealing with this situation responsibly is by maintaining the safety of the individual with PD. Therefore, caregivers are in a challenging situation that encourages them to seek ways to adapt and cope ${ }^{17}$ with the difficulties of this new daily reality, as after receiving diagnosis, there remain several uncertainties about the life of those being cared for, as well as the caregiver's own life.

Corroborating the findings of the present study, it was observed in another survey that 
most caregivers are women and the wives of the individual receiving care. These caregivers are usually aged over 50 , which makes them perceive care as a physically and emotionally draining function, though they clearly state that their partners would do the same for them ${ }^{17}$.Nevertheless, dealing with caring is also about learning to relax, to minimize the stress of exercising such a role, as a person's life does not stop when they become a caregiver. Therefore, the caregiver should be aware of the need to set aside time for self-care, and to feel attractive and good about oneself, because as was expressed in one study, the caregiver's own health is a latent concern, mainly because their role is often solitary ${ }^{17}$.

When a person with PD envisages reducing the burden of care, they consider the possibility of being institutionalized, however, according to Tan et al. ${ }^{17}$, the caregiver and the PD sufferer together consider that this is not the best option, as being close to one another more than one hour a day is fundamental to both parties ${ }^{17}$.
Some caregivers believe that it is useful to adopt a holistic approach to care ${ }^{17}$, which envisions the individual as an integral being. The implementation of care is generally hampered, however, by the presence of a number of obstacles which are mentioned in Figure 4, such as the high level of dependence on the part of the caregiver, who cannot leave their relative alone for a long period of time, resulting in the emergence of feelings of frustration ${ }^{18}$.

It is important to note that the health care and social service professionals connected to the process of care provided by the caregiver are often not prepared to discuss the end of life, which is as important a stage as any other. According to a caregiver from the study by McLaughlin et al. ${ }^{18}$ it is important to discuss palliative care with individuals who are afflicted with chronic diseases, not only those who have a terminal illness. However, many health professionals do not believe that this is appropriate, as PD is not terminal, but neurodegenerative ${ }^{18}$.

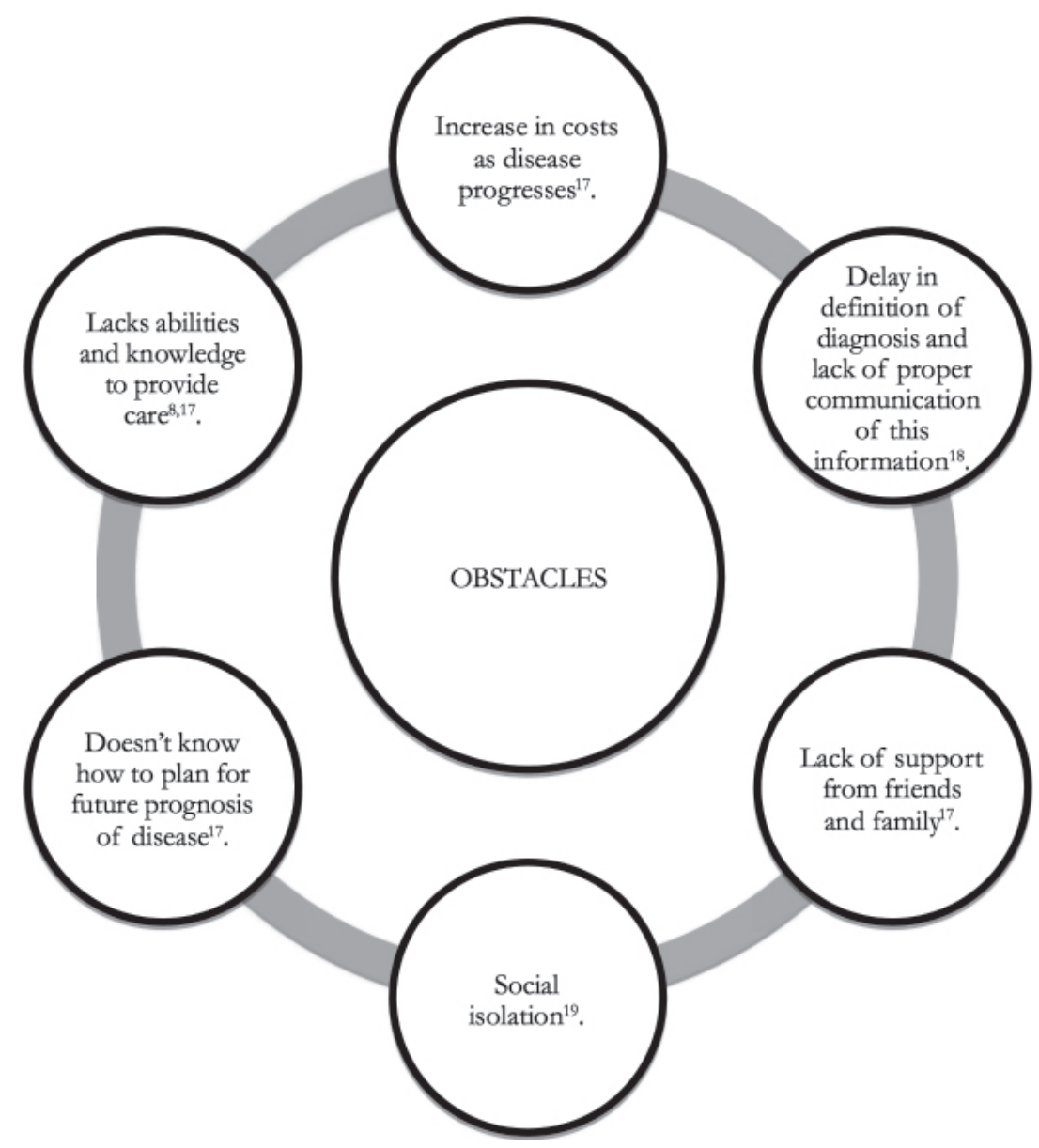

Figure 4. Flowchart of the number of articles found and selected after applying the inclusion and exclusion criteria. Recife, Pernambuco, 2015. 
The positive and negative aspects associated with the process of caring for a person with Parkinson's Disease

It can be perceived from the reports of the caregivers that the caring process can be experienced positively through social situations and closer family ties, such as the strengthening of the marital relationship through the assuming of joint responsibility. This finding was perceived among couples who did not have a good relationship before becoming caregivers. Thus, care can lead to emotional benefits, and even a feeling of gratitude, which encourages improvements in the lives of both parties ${ }^{17,18}$.

One negative aspect relates to the diagnosis of the disease, as according to one caregiver's report diagnostic confirmation can be delayed or inadequately communicated, resulting in shock and anger due to a lack of knowledge about PD, and fear ${ }^{18}$.

In addition, when there is a marital or family relationship between the caregiver and the individual with $\mathrm{PD}$, both may experience minor social deaths, which can begin in the work environment, with colleagues and friends, and even reach the family context ${ }^{19}$.
As described by caregivers, there may be restrictions to their lifestyle, which can lead to physical and emotional overload, and may or may not be associated with the difficulty of accepting a reversal of roles, such as in the case of parents and children, and the responsibility of the role ${ }^{17}$. Over time, the prognosis of PD requires the caregiver to provide and receive more physical, emotional and social support than in the initial stage. With increased demand for care, there may be a financial impact on family income, because caregivers sometimes need to give up their jobs, causing a serious loss of direct income ${ }^{18}$.

The mentally that "no one who can care for them as well as me" and the need to be always present prevents many caregivers from entrusting care to another caregiver. Whenever they are forced to do so, or to leave the individual with PD alone, feelings of guilt, worry and insecurity emerge ${ }^{17}$. The caregiver therefore needs a break from caring to improve their own quality of life ${ }^{18}$.

The association between the process of caring for an individual with PD and its positive and negative aspects allows us to reflect on how complex the daily construction of care is, as it demands resilience both on the part of caregivers and individuals with PD. The main aspects are shown in

Figure 5. Positive and negative aspects for caregivers of people with Parkinson's Disease. Recife, Pernambuco, 2015.

\begin{tabular}{|l|l|}
\hline Positive aspects & Negative aspects \\
\hline Increased personal maturity & Physical, emotional and social exhaustion \\
\hline Learn to act calmly & $\begin{array}{l}\text { Reduction in freedom/independence to plan one's daily } \\
\text { schedule }\end{array}$ \\
\hline $\begin{array}{l}\text { Seek out information about Parkinson's Disease and its } \\
\text { prognosis }\end{array}$ & State of alert \\
\hline Exercise more patience & Lack of integration in care network \\
\hline Exercise positive thinking & Emotional impact \\
\hline Improve family bonds/relationships & Undue concern with the opinion of others \\
\hline Feelings of joy & Restrictions on lifestyle \\
\hline Feeling of relief that is not malign tumor or dementia & $\begin{array}{l}\text { Feelings of worry, frustration, sadness, shock, loss, anger } \\
\text { and anxiety }\end{array}$ \\
\hline Improve family bonds/relationships & Making decisions alone \\
\hline
\end{tabular}




\section{Support for caregivers of people with Parkinson's Disease:} what can be done for them?

The discussion of this theme reveals how important it is to improve the support provided to the caregiver, either through the greater availability of information about PD and the management of the disease or accessibility to quality content ${ }^{17}$. This information will enable the caregiver to understand and deal with $\mathrm{PD}^{20}$.

Information related to the economic implications of the disease is as important as that related to caring, as there may be a financial burden related to the hiring of formal caregivers. According to the reports of the caregivers, this situation can be aggravated as a result of difficulties in accessibility to information about rights, benefits and social facilities ${ }^{18}$. It is important to emphasize that this information can facilitate the daily life of individuals with PD and their caregivers.

The caregivers described some factors related to the support they receive, such as: access to information; knowledge about PD and its prognosis; the creation of coping strategies; strength from spiritual beliefs; the development of a professional patient-caregiver relationship; volunteer groups to help people with PD and caregivers; maintaining social commitments; improvements in the health system and integrated care; family relationships; positive interpersonal relationships; and personal qualities desirable in a caregiver. The support network should be a part of the discussions of managers and health professionals in order to provide efficient and effective support to the caregiver. In this way, the anxiety, stress and helplessness reported by caregivers can be minimized ${ }^{18}$.

As explained by the caregivers, the health system needs to be improved through the adoption of an integrated approach to the provision of services for the care of PD by the multi-professional team, with the aim of seeking the best solutions ${ }^{17}$. Therefore, interdisciplinary actions across a network of services using referral and counter-referral as instruments to guide this reality can guarantee the biopsychosocial well-being of individuals with PD and their caregivers.
The lack of integrated and networked action means that health professionals do not focus on PD and are not aware of the services available for specialized care, and so can contribute to the occurrence of crises in these individuals ${ }^{18}$.

Therefore, the guarantee of a space where doubts about PD can be answered, mainly by the health professionals responsible for follow-up monitoring of a case, such as a neurologist, about the definition, progression, signs and symptoms, medication and its adverse effects, and advances in the treatment of PD is essential for quality health monitoring. This information should be made available based on the need/profile of each person affected by PD and their caregiver ${ }^{18}$.

Sometimes caregivers are not aware of the extent of the PD, and even health professionals are not usually the appropriate people to provide important details on such a subject, such as the presence of psychosis as an adverse effect of PD medication ${ }^{20}$.

The support given to the caregiver by others is fundamental to ameliorate the challenges of the caring process. One strategy might be the insertion of the caregiver into mutual support groups that allow the exchange of experiences and feelings among people who experience similarly situations. Many caregivers have perceived that these groups are a valuable tool in the carrying out of their role from the onset of $\mathrm{PD}$, as they can also reduce mental overload and anxiety ${ }^{9,17}$. In addition, it is important to change the perception of caregivers that they have no support from anyone, while the individual being cared for receives all the support of third parties ${ }^{17}$.

There is also a need to create groups for those with DP themselves ${ }^{18}$, as these individuals must be stimulated to deal with their disease the best they can, either through therapeutic groups or through the accompaniment of dentists, nurses, physiotherapists, speech-language pathologists and others.

With a significant number of elderly people providing care, it is important to emphasize that these individuals either are going through or will go 
through the process of human aging, which raises concerns regarding their own aging, during which they will probably also require care ${ }^{18}$.

The lack of research studies carried out in Brazil for the sample population is a limiting factor of the present work, and evidences the need to carry out studies that focus on the care of individuals affected by PD from the perspective of the family caregiver, so that this individual can be understood within the care process and in the context of their respective reality, considering the relevant cultural and social factors.

\section{CONCLUSION}

There is still a major shortage of publications about caregivers of people with Parkinson's disease. This failing is even more severe in Brazil, where a large majority of studies are directed at the individual affected by the disease itself.

Thus, caring for a person with Parkinson's disease is a challenge, considering that the caregiver's understanding of the health-disease process does not always occur in an adequate manner, which contributes to their physical and emotional exhaustion.

\section{REFERENCES}

1. Postuma RB, Berg D, Stern M, Poewe W, Olanow CW, Oertel W, et al. MDS Clinical Diagnostic Criteria for Parkinson's Disease. Mov Disord [Internet]. 2015 [acesso em 21 out. 2016];30(12):1591-9. Disponível em: http://onlinelibrary.wiley.com/doi/10.1002/ mds.26424/abstract;jsessionid=379A55D1C80C59F75 90B52CBA0324B4B.f03t03

2. Kalia LV, Lang AE. Parkinson's disease. Lancet [Internet]. 2015 [acesso em 20 out. 2016];386(9996):896-912. Disponível em: http://www. thelancet.com/journals/lancet/article/PIIS01406736(14)61393-3/abstract

3. Domingo EP. El libro blanco del Párkinson en España: aproximación, análisis y propuesta de futuro. España: Ministerio de Sanidad, Servicios y Igualdad; 2015.
The positive and negative aspects of the caring process, such as the strengthening of family ties and the restricting of the disease, involve access to information related to the disease and its prognosis. It is therefore imperative that health and social service professionals and managers are prepared to facilitate universal access to quality information, and to respond to questions about the same.

It is necessary to take care of caregivers through integral care services for individuals affected by Parkinson's, in order to guarantee the improvement of their functioning and reduce physical, emotional and social overload, which will directly influence the health of both parties. In addition, it is necessary to make society aware of the issues related to Parkinson's Disease in order to demystify the paradigms involving this condition, so that the network of support for people with Parkinson's and their caregivers is broadened and strengthened.

Therefore, there is a need for new studies that contribute to the understanding of this process from the perspective of the caregiver, including those affected by Parkinson's disease, especially in Brazil, considering that in this study no publications were found that adopted this perspective, which can be used to guide the creation of public policies for caregivers.

4. Born T. Cuidar melhor e evitar a violência: manual do cuidador da pessoa idosa [Internet]. Brasília, DF: Secretaria Especial dos Direitos Humanos; 2008 [acesso em 10 jul. 2015]. Disponível em: http://www. observatorionacionaldoidoso.fiocruz.br/biblioteca/_ manual/12.pdf

5. Ferreira DPC, Coriolano MGWS, Lins CCSA. Knowledge as a tool to promote care of the elderly with Parkinson's disease. J Nurs UFPE [Internet]. 2016 [acesso em 08 dez. 2016];10(12):4628-36. Disponível em: http://www.revista.ufpe.br/revistaenfermagem/ index.php/revista/article/view/9830/pdf_1886 
6. Boff L. Saber cuidar: ética do humano- compaixão pela terra. Petrópolis: Vozes; 1999.

7. Oliveira RC, Deutsch S, Garuffi M, Gobbi S. Interferência do estado de humor na melhora dos componentes da capacidade funcional em idosos. Estud Interdiscip Envelhec [Internet]. 2015 [acesso em 16 fev. 2016];20(1):285-96. Disponível em: http:// seer.ufrgs.br/index.php/RevEnvelhecer/article/ view/49521/34934

8. Silva APLL, Nobrega OT, Corte B. O olhar dos conselheiros de saúde da Região Metropolitana de São Paulo sobre serviços de saúde para idosos: 'Quem cuidará de nós em 2030?'. Saúde Debate [Internet]. 2015 [acesso em 23 jan. 2016];39(105):469-79. Disponível em: http://www. scielo.br/scielo.php?script=sci_arttext\&pid=S010311042015000200469\&lng=pt\&nrm=iso

9. Beyea SC, Nicoll LH. Writing an integrative review. Aorn J [Internet]. 1998 [acesso em 21 maio 2012];67(4):877-80. Disponível em: http://www. aornjournal.org/article/S0001-2092(06)62653-7/ fulltext

10. Mendes KDS, Silveira RCCP, Galvão CM. Revisão Integrativa: método de pesquisa para a incorporação de evidências na saúde e na enfermagem. Texto \& contexto Enferm [Internet]. 2008 [acesso em 15 maio 2015];17(4):758-64. Disponível em: http://www.scielo. br/pdf/tce/v17n4/18.pdf

11. Ursi ES, Galvão CM. Prevenção de lesões de pele no perioperatório: revisão integrativa da literatura. Rev Latinoam Enferm [Internet]. 2006 [acesso em 16 maio 2012];14(1):124-31. Disponível em: http://www. scielo.br/pdf/rlae/v14n1/v14n1a17

12. Melnyk BM, Fineout-Overholt E. Evidencebased practice in nursing $\&$ healthcare: a guide to best practice [Internet]. Philadelphia: Lippincot Williams \& Wilkins; 2005 [acesso em 10 ago. 2014. p. 3-24. Disponível em: http://download.lww. com/wolterskluwer_vitalstream_com/PermaLink/ NCNJ/A/NCNJ_546_156_2010_08_23_ SADFJO_165_SDC216.pdf
13. Critical Appraisal Skills Programme. Qualitative Research Checklist. Milton Keynes Primary Care Trust [Internet]. [sem local]: [sem editora]; 2013 [acesso em 19 ago. 2015]. Disponível em: http:// media.wix.com/ugd/dded87_29c5b002d99342f788c6 ac670e49f274.pdf

14. Volkmer C, Monticelli M, Reibnitz KS, Brüggemann M, Sperandio FF. Incontinência urinária feminina: revisão sistemática de estudos qualitativos. Ciênc Saúde Coletiva [Internet] 2012 [acesso em 04 set. 2015]; 17(10):2703-15. Disponível em: http://www. scielo.br/scielo.php?script $=$ sci_arttext\&pid=S141381232012001000019\&lng=en\&nrm=iso

15. Polit DF, Beck CT, Hungler BP. Fundamentos de pesquisa em enfermagem: métodos, avaliação e utilização. 5 ed. Porto Alegre: Artmed; 2004.

16. Freitas EV, Py L, editores. Tratado de Geriatria e Gerontologia. 3a . ed. Rio de Janeiro: Guanabara Koogan; 2011.

17. Tan SB, Williams AF, Morris ME. Experiences of caregivers of people with Parkinson's disease in Singapore: a qualitative analysis. J Clin Nurs [Internet]. 2012 [acesso em 14 fev. 2016];21:223546. Disponível em: http://onlinelibrary.wiley.com/ doi/10.1111/j.1365-2702.2012.04146.x/epdf

18. McLaughlin D, Hasson F, Kernohan WG, Waldron M, McLaughlin M, Cochrane B, et al. Living and coping with Parkinson's disease: perceptions of informal carers. Palliat Med [Internet]. 2011 [acesso em 22 ago. 2015];25(2):177-82. Disponível em: http:// www.ncbi.nlm.nih.gov/pubmed/20952448

19. Roland KP, Jenkins ME, Johnson AM. An exploration of the burden experienced by spousal caregivers of individuals with Parkinson's disease. Mov Disord [Internet]. 2010 [acesso em 10 ago. 2015];25(2):189-93. Disponível em: http:// onlinelibrary.wiley.com/doi/10.1002/mds.22939/pdf

20. Williamson C, Simpson J, Murray CD. Caregivers' experiences of caring for a husband with Parkinson's disease and psychotic symptoms. Soc Sci Med [Internet] 2008 [acesso 10 ago. 2015];67:583-9. Disponível em: http://www.sciencedirect.com/ science/article/pii/S0277953608002219 